\title{
Features of small business development in modern conditions: pandemic crisis and foreign experience
}

\author{
Bella Rakhimova ${ }^{1}$, Seda Aslakhanova,* \\ ${ }^{1} \mathrm{Kh}$. Ibragimov Complex Institute of the Russian Academy of Sciences, Staropromyslovskoe \\ highway, 21 a, Grozny, Russia \\ ${ }^{2}$ Kadyrov Chechen State University, Subra Kishieva Street, 33, Grozny, Russia
}

\begin{abstract}
The article analyzes the foreign experience of small business development in the context of the COVID-19 pandemic. In the course of the study, statistical methods of information processing and methods of comparative analysis were used. Small business is a priority tool for economic growth. The consequences of the current crisis are manifested in a decrease in the level of employment of the population and purchasing power, an increase in prices for goods and services, a change in the structure of the labor market and an increase in the level of poverty of the population. Small business sets itself the task of developing and implementing innovative technologies. This is especially relevant in new crisis conditions, when there is an active use of digital technologies and it is necessary to respond quickly and adapt to changes in the external environment. Therefore, the topic acquires its relevance and significance in the rapidly changing circumstances of the modern world.
\end{abstract}

\section{Introduction}

The main factors influencing the socio-economic development of the region are the level of employment and purchasing power, the level of investment and the volume of production. At the state level, various support measures are being taken for development of entrepreneurship through development and implementation of various state programs.

An important component of the socio-economic development of the region is the level of innovative development. In 2020, the share of innovative goods, works, services in the total volume of goods shipped, works performed, services of industrial production organizations amounted to $6.4 \%$, which is $0.3 \%$ more than in 2019 and $0.3 \%$ less for compared with 2017 [1].

To increase the innovative activity of the region, it is necessary to develop enterprises that carry out technological innovations. In 2020, the number of such enterprises in Russia was $23 \%$ against $21.6 \%$ of enterprises in 2019 and $7.3 \%$ of enterprises in 2016 [1].

"SMEs are in the best position to innovate in terms of their supply, as well as choosing the most suitable foreign markets, customers and suppliers" [11].

\footnotetext{
* Corresponding author: Zvezdochkagoodluck@mail.ru
} 
The key role in the socio-economic development of the state is assigned to small business, as the main instrument of the modern market economy system, ensuring creation of competitiveness of goods and satisfaction of consumer demand.

\subsection{Study Methods}

\subsubsection{Analysis of the Economic Situation in the Region in Crisis Conditions}

Let us emphasize that small business is a priority instrument for economic growth. The consequences of the current crisis are manifested in a decrease in the level of employment of the population and purchasing power, an increase in prices for goods and services, a change in the structure of the labor market and an increase in the level of poverty of the population.

According to Rosstat, in 2020 the share of the population with incomes below the subsistence level in Russia amounted to $12.1 \%$ or 17.8 million people against $10.8 \%$ of the population or 15.5 million people in 2013. Wherein, it shall be noted that from 2017 to 2019 inclusive, the share of the population with incomes below the subsistence level in Russia changed insignificantly: in 2017 - $12.9 \%$ (18.9 million people), in $2018-12.6 \%$ (18.4 million people), in 2019 - $12.3 \%$ (18.1 million people) [1].

In 2020, the employment rate among people aged 15 and over was $58.4 \%$, having changed slightly compared to previous years: in $2017-59.5 \%$, in $2018-59.8 \%$, in 2019 year $-59.4 \%[1]$.

The purchasing power of the average per capita monetary income of the population in the first quarter of 2020 was: beef $-91.3 \mathrm{~kg}$, lamb $-75.4 \mathrm{~kg}$, milk -465.7 liters, eggs 5121 pcs., butter $-51.1 \mathrm{~kg}$, salt $-2383 \mathrm{~kg}$, potatoes $-1385.6 \mathrm{~kg}$, onions $-1169.1 \mathrm{~kg}$, carrots $-1093.1 \mathrm{~kg}$. In 2020 , the purchasing power of the average per capita money income of the population changed insignificantly: beef $-100.9 \mathrm{~kg}$, lamb $-84.2 \mathrm{~kg}$, milk 523.6 liters, eggs -5680 pieces, butter $-56.9 \mathrm{~kg}$, salt $-2604.1 \mathrm{~kg}$, potatoes $-1276.0 \mathrm{~kg}$, onions $-1160.2 \mathrm{~kg}$, carrots $-1019.1 \mathrm{~kg}$. For 9 months of 2021 , compared to 2020 , there is a decrease in the purchasing power of the average per capita money income of the population. Thus, the purchasing power of beef was $97.6 \mathrm{~kg}$, carrots $-678.3 \mathrm{~kg}$, potatoes $896.5 \mathrm{~kg}[1]$.

Along with a decrease in the purchasing power of the average per capita money income of the population, there is an increase in average consumer prices for food products. So, in 2013 the price per $1 \mathrm{~kg}$ of beef was 244.55 rubles, and in $2020-361.04$ rubles. There is also an increase in prices for butter - from 308.92 rubles in 2013 to 638.69 rubles in 2020, milk - from 38.64 rubles in 2013 up to 59.32 rubles in 2020, eggs - from 56.01 rubles in 2013 up to 75.78 rubles in 2020 , potatoes - from 23.18 rubles in 2013 up to 29.15 rubles in 2020, and etc. [1].

The final result of the above consequences of crisis situations is the growth of social tension. Thus, there is an increase in the number of unemployed people over 15 years old. In 2020, the number of unemployed people over 15 years old was 4321.3 thousand people against 3969.5 thousand people in 2013 [1].

All this, ultimately, characterizes the market situation and forces enterprises to adapt to changes in the external environment.

\subsection{Small Business in the Post-Coronavirus Period}

Today, the state is implementing various programs for the effective development of entrepreneurial activities of the population. So, since 2018, the Federal Law "On 
Experimenting to Establish a Special Tax Regime“ Tax on Professional Income” dated November 27, 2018, No. 422-FZ has been in effect in Russia, which allows to sell products of own production and income for a calendar year shall not exceed 2.4 million rubles. A self-employed person pays $4 \%$ tax from the sale of goods to individuals, and $6 \%-$ to individual entrepreneurs and legal entities.

Note that small business plays not only an economic role, but also a social one, expressed in ensuring the level of employment of the population, creating favorable conditions for the population and attracting investment. In addition, small business sets itself the task of developing and introducing innovative technologies. This is especially relevant in new crisis conditions, when there is an active use of digital technologies and it is necessary to respond quickly and adapt to changes in the external environment.

In 2020, a number of measures were implemented at the state level to help small businesses. So, by mid-April 2020, 500 thousand inspections were suspended, a law was adopted on state provision of loans for payment of wages to employees at the level of 12,130 rubles, an interest-free loan was provided for 6 months for the payment of wages and the payment deadlines were extended by 6 months for income tax and the unified agricultural tax and advance payments for March and I quarter of 2020, for 3 months taxes on personal income, for 4 months - taxes on the patent taxation system for the II quarter of 2020 [2].

Small business, unlike large business, has insufficient financial capabilities for rapid restructuring in crisis situations. Crisis phenomena, expressed in an increase in prices for goods and services, a fall in the national currency, the introduction of quarantine measures to limit the activity of the population, a fall in purchasing power, have the most negative impact on small businesses.

The current pandemic crisis is radically different from previous crises. Unlike previous crises, the current crisis has caused global changes in the world and affected the life of all people. Thus, the US GDP in 2020 fell by $3.5 \%$. In the last, the largest decline in the GDP of the world economy was observed in 1946, when the GDP fell by $11.6 \%$ [3].

\subsubsection{Government Support for Small and Medium-Sized Businesses in Different Countries}

\subsubsection{Government Support for Small and Medium-Sized Businesses in the United States Amid a Pandemic}

Small business in the United States employs 58.9 million people or $47.5 \%$ of the total workforce in the private sector, whose contribution to the country's GDP amounted to 5.9 trillion dollars in 2014 [4]. To support the population during the pandemic in the United States, 2.2 trillion dollars was allocated. A total of 350 billion dollars has been allocated to support small businesses and individual entrepreneurs, which will help pay off the salary arrears of enterprises to personnel. However, this money was not enough and an additional 320 billion dollars was allocated. Enterprises will get an opportunity to get up to 10 million dollars at $1 \%$.

"High unemployment can be a signal to individuals that starting a new business will not pay off, and therefore, these people probably will not be looking for opportunities in the first place" [10].

Along with this, funds were allocated to support the population. For example, those who lost their jobs during the pandemic were paid 600 dollars every week. The category of citizens who received an annual salary of less than 75,000 dollars received payments of 1,200 dollars and 500 dollars for each child [5]. 
In addition, there is a program to compensate for economic damage in crisis situations to small businesses in the amount of 10 thousand dollars to pay for the costs of enterprises [6].

\subsubsection{Government Support for Small and MEDIUM-SIZED BUSINESSES in the UK Amid a Pandemic}

Along with the United States, quarantine was introduced in other countries, and measures were taken to support the population. GBP 39.7 billion has been allocated to support business and the UK population. GBP 750 million was allocated to support the charitable sector, and a deferral of VAT payments was introduced, rent payments were canceled and $80 \%$ of employees' salaries were compensated [6].

The UK government has allocated GBP 330 billion to support enterprises in a pandemic as part of a government loan guarantee program [6].

To support large businesses, the Bank of England's Covid Corporate Financing Facility program has been developed to raise working capital for companies by buying out shortterm corporate debts [6].

To support small businesses, the Coronavirus Business Interrupt Loan program has been developed, which will allow access to loans of up to GBP 5 million. The UK government has committed itself to cover the interest of the companies for up to 12 months [6].

Along with this, the UK government provided tax holidays for the payment of taxes, including property tax [6].

To support the employment level of the population, the Coronavirus Jobs Retention Scheme was developed and implemented, according to which the government pledged to pay $80 \%$ of the salaries of employees. Wherein, employers, at their discretion, can pay the remaining $20 \%$ of wages, and employees of the enterprise are exempted from the obligation to go to work, even if the employer pays full wages. However, this program has several disadvantages. So, those employees whose companies have gone bankrupt or are on the verge of bankruptcy cannot count on it. Also, the program does not apply to employees with reduced working hours, but did not fall to zero [6].

The UK government has taken measures according to The Self-Employed Income Support Scheme. According to the program, self-employed people with losses during the pandemic can count on support and have the right to claim only $80 \%$ of payments equal to the average income for the last three months. This program, like the above programs, has its drawbacks. So, self-employed with an income of more than 50 thousand pounds sterling per year and those who do not have a tax return for 2018-2019 cannot apply for it [6].

\subsubsection{Government Support for Small and Medium-Sized Businesses in Germany Amid a Pandemic}

Since March 23, 2020, quarantine restrictions have been in effect in Germany. To support the population and business in the context of the pandemic, 76 billion euros were allocated. In addition to support at the state level, the federal state governments have allocated 45 billion euros in support in the form of direct support and 63 billion euros in the form of loan guarantees at the state level [6].

At the state level, assistance is provided to enterprises on the verge of bankruptcy. Twice as many loans are allocated to support the economy from the economic stabilization fund [6].

50 billion euros are allocated to small businesses and the self-employed persons. Employers with a staff of at least 5 people and self-employed persons can count on 
payments of 9 thousand euros, employers with a staff of up to 10 people receive support in the amount of 15 thousand euros [6].

For a period of 6 to 10 years, they provide loans to enterprises under the programs "KfW-Sonderprogramm 2020", "KfW-Schnellkredit 2020". Funds of up to 1 million euros have been allocated to support young start-ups [6].

Just like in the UK, Germany has introduced tax deferrals or reductions if the company is experiencing difficulties in paying them [6].

In addition, in order to preserve employment of the population, companies whose employees have been reduced working hours by up to $10 \%$. It shall be noted that earlier, for provision of state support, the threshold for reducing working hours shall not exceed 30 $\%[6]$.

For those who are sick with COVID-19, in the first 6 weeks the amount of wages is paid, and then - in the amount of sickness benefit [6].

The part of employees who work as self-employed persons receive financial assistance in the amount of up to 15 thousand euros for 3 months [6].

In 2020, 7.7 billion euros were allocated for social support of the self-employed persons [6].

\subsubsection{Government Support for Small and Medium-Sized Businesses in France in the Face of a Pandemic}

In France, quarantine was introduced earlier than in the above countries, from March 16, 2020. The cost of anti-crisis measures amounted to 376 billion dollars, or $14 \%$ of the GDP [6].

At the state level, tax deferrals have been granted in France. To support enterprises, self-employed persons and individual entrepreneurs, 32 billion euros have been allocated [6].

In order to provide assistance to the population, an allowance of 27 euros is paid for each closed place in a public institution. To support the population in private institutions, an allowance of 17 euros is paid. More than 8.7 million people were transferred to remote operation. It costs the state 24 billion euros. Along with this, compensation for underemployment is paid, which covers at least $70 \%$ of wages. In addition, there is a limit of monthly compensation in the amount of 4.5 minimum wages or 5,485.5 euros. The same employees who receive the minimum wage are paid $100 \%$ compensation from the state [6].

Small businesses, self-employed and sole proprietors received support in the form of financial assistance in the amount of 1,500 euros at a time. During the pandemic, financial assistance was provided to 600 thousand enterprises, in a total amount of 2 billion euros. Note that this assistance was provided to those enterprises whose annual turnover did not exceed 1 million euros [6].

\section{Study Results}

Amid the COVID-19 pandemic, small businesses around the world are in dire straits, facing an unstable economic environment. Despite the fact that all over the state level support is provided to small businesses, some of the enterprises went bankrupt and were forced to close. Among the small businesses most severely affected by the COVID-19 pandemic, we note the catering establishments that only worked to go. Fitness rooms and entertainment centers have been completely closed. Beauty salons and hairdressing salons 
suffered losses. As we can see, the main damage was incurred by the service sector enterprises.

In 2010, the share of SMEs in Russia's GDP was 19.9\%, in 2018 this indicator improved markedly and reached $20.2 \%$, but during the coronavirus crisis the share of the SMEs in GDP decreased and reached $19.8 \%$ [7].

In 2010, the share of people employed in the SMEs was $27 \%$, in 2018 this indicator changed insignificantly and amounted to $27 \%$, in 2020 the indicator changed and turned out to be at the level of $2010-27 \%$ [7].

During the pandemic, $56.1 \%$ of companies were quarantined, the turnover of small businesses in the coronavirus 2020 decreased by 3.1 trillion rub. Along with this, from $20 \%$ to $30 \%$ the share of small businesses with debt on loans increased from the total number of small businesses [7].

During the pandemic, the state provided financial assistance to small businesses, which made it possible to compensate for the losses incurred, however, already in the first quarter of 2021, there was a drop in demand by $13 \%$ [7].

In the post-coronavirus period and the termination of state support, the situation of small businesses has worsened due to a drop in demand and income [7].

In 2020, $42 \%$ of small and medium-sized businesses received state support. Entrepreneurs note that the best support measures were the reduction of the tax burden and subsidies for the payment of wages [7].

According to surveys conducted, $39.3 \%$ of entrepreneurs assess the state of the economy as satisfactory, $30.4 \%$ - bad, $15.2 \%$ - very bad [7].

Regional support measures are assessed positively by $29.84 \%$ of entrepreneurs, $41.3 \%$ - negatively [7].

The main problems of small and medium-sized businesses include administrative pressure, imbalance in the tax system, lack of profit growth, insurance premiums, bureaucracy, high level of secured lending, and etc. [7].

\section{Result Discussion}

In the post-coronavirus period, some small and medium-sized businesses have transferred some of their employees to a remote mode of work. In crisis conditions, enterprises which promptly respond to changes in the external environment survive. If we talk about the positive aspects of the transition of workers to a remote mode of work, then it is worth noting the reduction in time and transport costs. On the other hand, the introduction of quarantine restrictions led to the fact that some of the employees changed their field of activity.

"In Russia, the Concept of long-term socio-economic development until 2020 was developed, but the outbreak of the global financial crisis in 2008 made its implementation impossible. Instead, Strategy 2020 was approved, according to which the GDP growth per year was supposed to be $6 \%$, but by 2018 this figure was $2 \%$. According to forecasts of the Ministry of Economic Development, by 2024, the GDP growth by 2024 will amount to $4 \%$ per year. The indicator for reducing the poverty level of the population from $13 \%$ to $6 \%$ remained unchanged; now it is planned to achieve this indicator by 2024. All developed strategies were aimed at increasing the competitiveness of the national economy. In the modern world, small and medium-sized businesses are an indispensable tool for the country's socio-economic development, increasing competitiveness and creating favorable conditions for the business sector" [8]. 


\section{Conclusions}

Therefore, we can note the key role of small and medium-sized businesses in the socioeconomic development of the region. Small and medium-sized businesses are aimed at solving problems such as meeting the needs of the population, producing competitive products. Despite the pandemic crisis, small and medium-sized businesses are trying to increase the pace of production and use digital technologies in expanding markets for their products.

Based on the above, we will highlight the main recommendations for development of small business in a pandemic crisis:

Firstly, in order to maintain the level of employment in the conditions of quarantine restrictions, it is necessary to transfer some employees to a remote mode of work.

Secondly, in the context of the transition to the online format, there is a need for couriers, therefore, it is necessary to create own logistics delivery.

Thirdly, in the conditions of the online regime, the demand for digital technologies is increasing.

In other words, for effective operation, enterprises need to analyze the external environment, identify opportunities and risks, analyze competitors and study the advantages and disadvantages of the service provided, and etc.

In crisis situations, the most popular are the areas of small business for creating websites, cleaning apartments or houses, making semi-finished products and desserts, and etc.

Today, the state is developing and implementing programs to support small and medium-sized businesses using digital technologies. Note that the COVID-19 pandemic had a huge impact on all sectors of the economy and made significant changes to it. In such conditions, only a small part of entrepreneurs was able to adapt to the new conditions. Already today, entrepreneurs have been able to assess the positive aspects of employees' transition to a remote mode of work. Based on the foregoing, we emphasize that among the main support measures provided to small businesses around the world, there are deferred tax payments, the allocation of loans for payment of wages and cancellation of rental payments.

Despite the ongoing support measures, it is necessary to expand programs to support small businesses and create favorable conditions for small businesses in order to increase their competitiveness on a par with big business.

\section{References}

1. Federal'naya sluzhba gosudarstvennoj statistiki (2021). Access mode: https://rosstat.gov.ru/

2. L. M. Idigova, B. H. Rahimova, S. U. Gapaeva, Cifrovizaciya i predprinimatel'skaya deyatel'nost': problemy $i$ perspektivy razvitiya $v$ usloviyah koronavirsunogo krizisa, Problemy ekonomiki i upravleniya neftegazovym kompleksom, 2(194), 28-32 (2021). Access mode: https://www.elibrary.ru/item.asp?id=44639879\&

3. VVP SSHA pokazal rekordnoe padenie s 1946 goda (2021). Access mode: https://www.rbc.ru/economics/28/01/2021/6012eb679a7947f350239438

4. C. Monson, What Small Businesses Need to Survive the Coronavirus Crisis, Harvard Business Review (2020). Access mode: https://hbr.org/2020/03/what-small-businessesneed-to-survive-the-coronavirus-crisis

5. 90 tysyach rublej kazhdomu: kak v drugih stranah pomogayut lyudyam vo vremya pandemii (2020). Access mode: https://journal.tinkoff.ru/list/save-business/ 
6. T. A. Bazhenova, O. V. Voron, E. S. Gorvat, N. B. Grishchenko, E. B. Deminceva, D. E. Kareva, D. S. Kashnickij, I. S. Kashnickij, M. A. Nagernyak, L. N. Ovcharova, D. O. Popova, O. V. Sinyavskaya, M. A. Ustinova, Obzor mezhdunarodnoj praktiki podderzhki ekonomiki $i$ naseleniya $v$ usloviyah bor'by s pandemiej koronavirusa $v$ Armenii, Velikobritanii, Germanii, Danii, Ispanii, Italii, Kazahstane, Kitae, Niderlandah, SSHA, Finlyandii, Francii, SHvecii, Yuzhnoj Koree, Yaponii, Institut social'noj politiki NIU VSHE (2020). Access mode: https://isp.hse.ru/data/2020/04/29/1544579194/COVID19 stimulus $\% 20$ packages countries260420.pdf

7. Special'nyj doklad Prezidentu Rossijskoj Federacii «MSP/Postkovid. Vremya dlya sistemnyh reshenij» (2021). Access mode: http://doklad.ombudsmanbiz.ru/2021/7.pdf

8. B. Kh. Rakhimova, S. A. Aslakhanova, Issues of developing the digital economy in Russia, EUROPEAN PROCEEDINGS OF SOCIAL AND BEHAVIOURAL SCIENCES EPSBS, 2415-2419 (2021). Access mode: https://www.elibrary.ru/item.asp?id=45791472,http://doklad.ombudsmanbiz.ru/2021/7. pdf

9. B. Kh. Rakhimova, S. A. Aslakhanova, Formation and development of urban logistics in the context of digital transformation, EUROPEAN PROCEEDINGS OF SOCIAL AND BEHAVIOURAL SCIENCES EPSBS, 765-773 (2021). Access mode: https://www.europeanproceedings.com/files/data/article/10076/14988/article_10076_1 4988 pdf 100.pdf

10. M. Stuetzer, M. Obschonka, U. Brixy, et al., Regional characteristics, opportunity perception and entrepreneurial activities, Small Bus Econ, 42, 221-244 (2014). Access mode: https://doi.org/10.1007/s11187-013-9488-6

11. M.-C. Stoian, J. Rialp, P. Dimitratos, SME Networks and International Performance: Unveiling the Significance of Foreign Market Entry Mode, Journal of Small Business Management, 55, 128-148 (2017). Access mode: https://www.webofscience.com/wos/woscc/full-record/WOS:000392605200006 